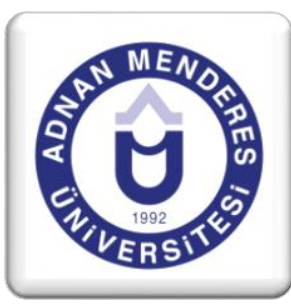

\title{
E-Wom'un Tüketicilerin Tatil Satın Alma Niyetine Etkisi
}

\author{
Fatma ÇAKIR, Nurhan AYBAR, Gökhan AKEL
}

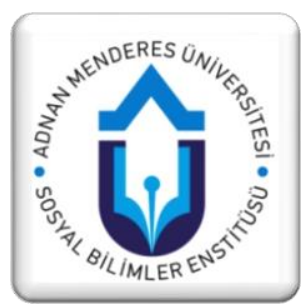

\section{ÖZET}

Satın alma kararı aşamasında, tüketiciler için ağızdan ağıza iletişim (word of mouth-WOM), en önemli bilgi kaynağı olarak karşımıza çıkmaktadır. Bunun sebebi, özellikle elle tutulması ve değerlendirmesi imkansız olan turizm ürün ve hizmetlerinde daha da önemlidir. Yaşamımızın her alanına dâhil olan internet, toplumumuzda en önemli iletişim araçlarından birisi olmasının yanı sıra, bireylerin ticari hayatlarında da önemli bir rol üstlenmiştir. İnternet sayesinde birbirleriyle doğrudan bağlantılı (çevrimiçi) olan kullanıcılar herhangi bir konuda bilgi alışverişine girerek birbirlerini etkilemektedirler. Herkese açık forumlarda satın alınan ürünler hakkında yapılan yorumlar kişilerin satın alma kararlarında etkili olmaktadır. Literatürde çevrimiçi görüşlerin satın alma kararına pozitif ve negatif etkilerini değerlendiren birçok çalışma bulunmaktadır. Bu çalışmada da tüketicilerin tatil tercihinde satın alma öncesi okudukları çevrimiçi görüşlerin satın alma kararına etkisi ölçülmüştür. Bu amaçla geçerliliği ve güvenirliliği test edilen anket formu tesadüfi olmayan örneklem yöntemi ile 222 kişi üzerinde uygulanmıştır. Tüketicilerin demografik verileri, internet kullanım sıklığına ve satın alma kararına çevrimiçi görüşlerin etkilerine ait veriler SPSS 23 programı ile analiz edilmiştir. Çevrimiçi görüşlerin niteliklerini belirlemek için ise faktör analizinden yararlanılmıştır. Faktör analizinde çevrimiçi görüşler ile ilgili olarak boyutlar belirlenmiştir. Boyutlar arası ilişkiler istatistiksel analizlere tabi tutulmuştur.

Anahtar Kelimeler ; E-Wom, Tüketicilerin Tatil Tercihi, Satın Alma Kararı

\section{The Effect of E-Wom on Consumers' Holiday Purchasing Intention}

\begin{abstract}
In the stage of purchasing decision, the word of mouth communication for consumers is the most important source of information. The reason for this is even more important in tourism products and services, which are especially tangible and impossible to assess. The internet, which is included in every aspect of our lives, plays an important role in the commercial life of individuals as well as being one of the most important means of communication in our society. Users are interacting with each other by exchanging information with each other through the internet. Everyone's comments on products purchased in open forums are influential in the purchasing decisions of the people. There are many studies in the literature evaluating the positive and negative effects of online opinions on purchase decision. In this study, consumers' pre-purchase online opinions for holiday preferences were measured for purchase decision. For this purpose, the validity and reliability of the questionnaire was tested by random sample method with 222 people. Demographic data of consumers were analyzed by the SPSS 23 program, which measures the frequency of internet use and the effects of online opinions on purchasing decisions. Factor analysis was used to determine the qualities of online opinions. In the factor analysis, dimensions related to online opinions were determined. Relations between dimensions were subjected to statistical analysis.
\end{abstract}

Keywords; E-Wom, Holiday Preferences of Consumers, Purchasing Decision 


\section{Giriș}

İnternet kullanımının giderek yaygınlaşması ile birlikte, çok daha fazla tüketici eski tüketici deneyimlerini çevrimiçi olarak paylaşmaktadır (Luo vd., 2013: 92). Bloglar, çevrimiçi görüşler ve sosyal ağlar tüm ürün çeşitleri, servisler ve markalar hakkında müşterilerin sanal olarak etkileşime girmelerini ve bilgi ve fikir paylaşımında bulunmalarını sağlamaktadır (Filieri ve McLeay, 2013: 44). Böylece, kişisel etkinin saygıdeğer konusu artık çevrimiçi kişiler arası etki ya da elektronik ağızdan ağıza iletişim (e-wom) olarak onun siber uzaydaki uzantısını da içermektedir (Goldsmith ve Horowitz, 2006:3).

Bir hizmet sektörü olan turizm sektöründe de çevrimiçi görüşlerin önemi büyüktür. Gidilen oteller ile ilgili yapılan yorumlar ve paylaşılan tatil deneyimlerinin hepsi tatili için karar aşamasında olan tüketiciyi olumlu ya da olumsuz etkilemektedir. Paylaşılan bu görüşlerin kritik öneme sahip olmasının sebebi ise turizm ürünlerinin maddi olmayan ürünler olarak, tüketilmesinden önce değerlendirilememesidir; bu da e-wom'un önemini artırmaktadır (Litvin vd., 2006: 2).

Bu çalışmada tüketicilerin tatil satın almadan önce internette okudukları görüşlerin satın alma kararlarını ne ölçüde etkilediği araştırılmıştır. Ayrıca çalışmada tüketicilerin web sitelerindeki görüşlere dayalı olarak tatil tavsiye etme durumu da incelenmiştir.

\section{Literatür Taraması}

\subsection{WOM (Word of Mouth-AğızdanAğıza İletişim)}

Bilgi teknolojisinin ortaya çıkmasından önce ağızdan ağıza pazarlama, bir tüketici deneyiminin arkadaşlar ve akrabalar arasında yayılması anlamına geliyordu (Viglia vd.,:2016:2036). Başka bir tanımla ağızdan ağıza iletişim (wom), özel ürünlerin mülkiyetleri, kullanımları, özellikleri, servisleri ve satıcıları hakkında diğer tüketicilerle yapılan gayri resmi iletişimlerdir (Westbrook, 1987, p. 261). Günlük hayatta kullanılan ürünler veya alınan hizmetler ile ilgili bulunulan ortamlarda yapılan yorumlar, değerlendirmeler ve iyi ya da kötü tavsiyeler bu ürünü ya da hizmeti kullanacak ya da kullanmayı düşünen diğer kişiyi etkilemektedir. Bu yüzden wom piyasadaki en etkili pazarlama kanallarından biridir (Fan vd.,2013:58). Ağızdan ağıza pazarlamada amaç, tüketicileri kampanyanın bir parçası haline getirerek, onları bir marka elçisine dönüştürerek, kuruluşun satış elemanı gibi davranmalarını sağlamaktır yani, hedef tüketiciye bir mesaj iletmekten ziyade, tüketicilerle birlikte bir mesaj yaratmaktır (Kalpaklığlu, 2015:72). Bu birçok pazarlama tekniğinden daha güçlüdür çünkü, doğrudur, hızlıdır, ucuzdur ve perakende bilgileri sağlar (Aslam vd., 2011:506). 


\subsection{E-WOM (Electronic Word of Mouth-Elektronik Ăğıdan Ăğıa}

\section{İletişim)}

İnternetin yaşamın her alanına dahil olmasıyla birlikte geleneksel wom yerini e-wom'a bırakmıştır. Elektronik ağızdan ağıza iletişim (e-WOM) potansiyel, mevcut ya da eski müşterilerin bir ürün ya da şirket hakkında olumlu veya olumsuz görüşleridir ve bu görüşler internet yoluyla çok sayıda kişinin ve kuruluşların kullanımına sunulmaktadır (Thurau vd., 2004: 39). Chevalier ve Mayzlin (2006) çevrimiçi kullanıcı görüşleri çeşitli ürün kaliteleri hakkında ağızdan ağıza iletişimin diğer formlarını değiştirerek ve tamamlayarak tüketiciler için önemli bir bilgi kaynağı haline geldiğini söylemektedir. E-wom geleneksel ağızdan ağıza iletişimle karakteristikler açısından büyük benzerlikler göstermesine rağmen, wom'a tamamen yeni bir bakış açısı sunar (Al Mana, Mirza, 2013: 23).

E-Wom tüketici incelemelerinde, tüketicilerin ürün incelemelerini yayınlamak için yalnızca bilgisayarlarıyla etkileşime girmesi gerekir. Onların görüşleri diğer tüketicilerin kullanımına geniş ve kolay şekilde erişilebilir durumdadır. Diğer tüketiciler incelenen ürünlerin türü hakkında bilgi aramak için onlara erişebilirler (Sen ve Lerman, 2007:77). Yani, e-WOM, başkalarına hedef ürüne bakış açısı sağlamak için bir dizi ürün özelliklerini tartışan birden çok tüketiciden kaynaklanmaktadır (Sparks ve Browning, 2011:1312).

Çevrimiçi alışveriş yapan tüketiciler perakende satış mağazasında olduğu gibi ürünlere dokunamaz ya da koklayamazlar; bu yüzden onların satın alma kararları web sitesinde sunulan ürün bilgisine dayanmaktadır (Park vd., 2007: 125). Buna göre web sitelerinde sunulan görüşler ya ürünü destekleyen pozitif görüşlerdir ya da ona karşı olan negatif görüşlerdir (Sen ve Lerman, 2007: 77). Pozitif e-wom ile karşılaştırıldığında negatif ewom'un satın alma kararında daha güçlü etkiye sahip olacaktır (Chang ve Wu, 2013: 206). $\mathrm{Bu}$ yüzden firmalar etkili internet pazarlama stratejileri oluştururken tüketicilerin satın alma niyetine e-wom'un etkisini dikkate almalıdır (Park ve Lee, 2009: 61).

Pazarlama üzerine yapılan birçok çalışmada e-wom'un tüketim üzerindeki etkisine dikkat çekilmektedir. Çünkü e-wom satın alma kararını, karar sürecini ve satın alma niyetini birçok yönden etkilemektedir. Thurau ve Walsh (2003) yaptıkları çalışmada faktör analizi ile "satın alma ile ilgili bilgileri edinme", "bilgi yoluyla sosyal yönlendirme", "topluluk üyeliği", "ücretlendirme" ve "ürünü tüketenden öğrenmek" şeklinde 5 faktör boyutu elde etmiş ve ewom'u en çok etkileyen faktörün satın alma ile ilgili bilgileri edinme olduğunu tespit etmiştir. Almana ve Mirza (2013) çevrimiçi tüketici görüşlerini "görüşlerin özellikleri”, "görüş yazanların özellikleri" ve "görüşlerin sunulduğu web sitesinin özellikleri” olmak üzere 3 faktör atında birleştirmiştir. Yapılan çalışmanın sonucunda yüksek derecelendirme ve görüşlerin özelliklerinin satın alma kararını en çok etkilediği görülmüştür. Ayrıca özellikle tutarlılık, çevrimiçi görüşlerin sayısı ve görüşlerin yakın zamanda yapılmış olması satın alma kararlarında önemli faktörlerdir (Almana ve Mirza, 2013:30). Wei vd., (2014) ewom'un rezervasyon niyetine etkisini 5 boyut olarak incelemişlerdir, bunlar: "algılanan ewom güvenilirliği", "pozitif çevrimiçi görüşler", "negatif çevrimiçi görüşler”, "e-wom kullanıcısının uzmanlığı" ve "e-wom kullanıcısının ilgilenimi". Ancak "algılanan e-wom 
güvenilirliği" ve "negatif çevrimiçi görüşler"in istatistiksel açıdan anlamlı olarak rezervasyon niyetini etkilemediğini bulmuşlardır.

Çevrimiçi tüketici görüşleri, reklam mesajlarının aksine tüketiciler için ikili bir rol oynamaktadır. Bilgi veren ve tavsiye veren rollerinin ikisi de tüketicinin satın alma niyeti ile pozitif yönde ilişkilidir (Park vd., 2007:140).

Yapılan çalışmalar genellikle tüketicilerin bilgi paylaşma faktörlerine odaklanmıştır. Tüketicilerin satın alma kararında çevrimiçi tüketici görüşlerinden faydalanılmasına sebep olan faktörlere çok az dikkat edildiğini belirten Cheung vd. (2008) yaptıkları çalışmada görüş kalitesi ve kaynak güvenilirliğinin bilgi kullanışl1lı̆̆ına ve onun da bilgiyi benimsemeye etkisini incelemişlerdir. Sonuç olarak da bilgi kullanışlılığının, çevrimiçi topluluklardaki bilgileri benimseme kararında tüketici üzerinde güçlü ve önemli bir etkisi olduğunu elde etmişlerdir.

Tüm sektörlerde pazarlamanın önemli bir unsuru olarak karşımıza çıkan çevrimiçi tüketici görüşleri, turizm sektöründe de etkilidir. Tüketicilerin çoğunun çevrimiçi tatille ilgili değerlendirmeleri satın almadan önce kullandıklarını görüyoruz ve tüketiciler iki nedenden dolayı bu yazılanları okuyorlar: tavsiye edilen aktiviteleri araştırmak ve muhtemel yeni yazılan görüşleri taramak (Chen vd., 2015:963). Kalpaklığlu'nun (2015) araştırma sonuçlarından da görüleceği gibi bireyler tatil satın alırken gerek çevrelerinin gerekse blog yazarlarının tavsiyelerinden etkilenmektedirler yani, turizm işletmeleri açısından müşteri tatmini ön plan çıkmaktadır. Yaptığı tatilden, aldığı hizmetten memnun olan müşteri tavsiye yoluyla hizmet aldığı firmaya birçok müşteri çekebilir. Böylelikle kurulan iyi iletişim sayesinde memnun müşterinin firmanın maliyetsiz bir pazarlama elemanı haline dönüşmesi mümkündür. Viglia vd. (2016) yaptıkları çalışmada çevrim içi platformlardaki, 1-10 arasına dönüştürülmüş, yazılan bir görüşün ortalama gözden geçirme puanında bir puanlık artışının 7.5 puanlık doluluk oranındaki bir artışla ilişkili olduğunu bulmuştur. Bu durum, otel kârlılığı için kurulucak modellerde çevrimiçi gözden geçirme hususlarının da dahil edilmesini önerir. Bulgular, daha az keşfedilen bir otel performans göstergesini (otel doluluk durumu) farklı oteller ve çeşitli çevrimiçi gözden geçirme kaynaklarını dikkate alan kapsamlı bir metodolojiyle analiz ederek e-wom ile ilgili mevcut literatüre katkı sağlamıştır (Viglia vd.,:2016:2045).

\section{Metodoloji}

$\mathrm{Bu}$ çalışma e-wom'un tüketici görüşleri, güvenilirlik-geçerlilik, ilgilenim ve inanılırlık boyutlarının satın alma karar aşamasında olan tüketicinin satın alma kararına ve tüketicinin tatili tavsiye etmesine olan etkisi ölçülmüştür. Bununla birlikte demografik özelliklerin ewom boyutlarıyla olan ilişkileri belirlenmiştir. $\mathrm{Bu}$ model için kurulan iki ana hipotez aşağıdaki gibidir:

$\mathrm{H}_{1}$ : E-wom faktörleri ile tüketicilerin tatil satın alma niyeti arasında bir ilişki vardır.

$\mathrm{H}_{2}$ : E-wom faktörleri ile tüketicilerin tatili tavsiye etmesi arasında bir ilişki vardır. 

edilmiştir.

$\mathrm{Bu}$ ana hipotezlere bağlı olarak demografik özelliklerde alt hipotezlerde test Araştırmanın anketi kolayda örnekleme yöntemiyle çevrimiçi olarak uygulanmış ve 222 analize elverişli şekilde anket sonucu elde edilmiştir. Ankete katılanlar kişiler 18 yaş ve üstü öğrenciler, çalışanlar, çalışmayanlar ve emeklilerden oluşmaktadır. Bununla birlikte farklı eğitim düzeyine, farklı gelir düzeyine ve mesleğe sahip kişilerin oluşturduğu örneklem çalışmanın kapsamını genişletmektedir.

Literatürde Thurau ve Walsh 2003 de yaptıkları çalışmada müşterilerin neden diğer müşterilerin çevrimiçi görüşlerini web tabanlı tüketici görüş platformlarından aldıklarını açıklayan nedenleri ortaya çıkarmıştır. Yaklașık 2,900 Alman platform kullanıcısı üzerine yapılan ampirik bir çalışma, okuyucuların bilgi içeriğini özellikle önemli gördüklerini göstermiştir çünkü daha iyi satın alma kararları vermeleri ve daha kısa sürede aramalarını tamamlamaları sağlanmaktadır.

Thurau vd.'nin 2004 de yaptıkları çalışmada ise yaklaşı 2.000 tüketicinin çevrimiçi bir örneğini kullanarak, tüketicilerin çevrimiçi görüş yazmalarının sebeplerinin yapısı ve bunlarla alakalılığı hakkında bilgi verilmiștir. Ortaya çıkan analiz göstermiștir ki, tüketicilerin sosyal etkilesim isteği, ekonomik tesvikler icin arzu, diğer tüketiciler icin endiseleri ve kendi öz değerlerini gelistirme potansiyelleri, e-wom davranısina neden olan birincil faktörlerdir.

Park vd. (2007) 'nin çalısmasında tüketici görüslerinin kalitesinin ve miktarının satın alma niyetini nas1l etkilediği arastırılmıstır. 352 gönüllü üniversite öğrencisinin katıldığ çalısmada çevrimiçi incelemelerin kalitesinin, tüketicilerin satın alma niyeti üzerinde olumlu etkiye sahip olduğu ve ayrıca incelemelerin sayısının arttıkça satın alma niyetinin de arttığ görülmüstür.

Khammash 2008 de cevrimici görüssleri okumaya neden olan güdüleri ve onların tüketim alıskanlığ1 davranısları üzerindeki etkisini büyük ölcekli bir niceliksel ankette 1010 kisiye bu anketi uygulayarak test etti. Sonuçta en çok müssteri deneyimlerinden faydalanmak için çevrimiçi görüslerin okunduğunu ve pozitif e-wom'un satın alma niyetini negatif e-wom'dan daha fazla etkilediği sonucuna varmıstır.

Cheung vd. (2009) yaptikları calısmada bilgilendirici ve normatif belirleyicilerin cevrimiçi tüketici önerilerinin algılanan güvenilirliğini nassl etkilediğini araştırmışlardır. CCin'de yaygın olarak kullanılan bir tüketici forumunda kullanicilar mail yoluyla ankete katılima davet edilmiş ve 159 kișiden verimli yanıt alınmıștır. Sonuç olarak algılanan e-wom güvenilirliğinin, e-wom incelemesinin benimsenmesine olumlu etki yaptı̆ğ bulunmustur.

Almana ve Mirza'nın (2013) arasttırması cevrimiçi incelemelerin Suudi vatandaşlarının cevrimiçi satın alma kararlarına etkileri üzerinedir. Yapılan anket sonucu elde edilen bulgular, Suudi İnternet alısveriscilerinin e-wom'dan cok etkilendiğini ve İnternet üzerinden ürün satın almak icin kararlar alırken daha büyük bir yüzdesinin cevrimici forumlara bağl1 olduğunu göstermektedir. 
Son olarak Wei vd., (2014) calısmasinin temel amac1, otel müsterilerinin rezervasyon niyetini tetikleyen eWoM faktörlerini belirlemektir. Malezya'nın Kuala Lumpur kentinde secilen 10 otel arasından secilen 500 müsteriye anket elden verilmistir. Regresyon analizi sonuçlarına göre de rezervasyon niyetini etkileyen 3 e-wom faktörünün pozitif e-wom, tüketici deneyimleri ve tüketici ilgilenimi olduğu bulunmustur.

Bu calısmada e-wom'un tüketici görüșleri faktörü için Thurau vd.:. (2003), Khammash (2008) ve Almana ve Mirza (2013), güvenilirlik-geccerlilik faktörü için Thurau vd... (2003), Thurau vd. (2004) ve Almana ve Mirza (2013), ilgilenim faktörü için Park vd.,.(2007), Wei vd., (2014) ve son olarak inanıl1rlık faktörü için Cheung vd. (2009) ve Wei vd., (2014). calısmalarından yararlanılmıstır.

Katılımcıların tatil satın alma kararında ve tavsiye etmesinde e-wom'dan ne derece etkilendiklerini ölçmek için anket formunda demografik soruları da içeren toplam 26 soru sorulmuştur. Formda 5'li Likert tipi ölçekten (1-hiç katılmıyorum, 5-kesinlikle katılıyorum) yararlanılmıştır.

Anket formundaki ifadelerin 6 tanesi (1-6) demografik özelliklerle ilgilidir. Diğer ifadeler SPSS 23 paket programında incelenerek faktör analizine tabi tutulmuştur. Ancak bu analiz esnasında "İnternetteki tatil ve tur hizmet değerlendirmelerinin, tarafsız olduğunu düşünüyorum”, “ tatil satın almadan önce görüşleri okuyarak bilgi sahibi olmak, bana satın alma karar sürecimde vakit kazandırır" ve "tatil satın almadan önce görüşleri okumak bana daha fazla parasal fayda sağlar" ifadeleri anketi cevaplayanlar tarafından doğru algılanmadığı anlaşıldığı için anketten çıkarılmıştır. Kalan ifadeler ile yapılan faktör analizinde 4 boyut elde edilmiştir. Bu çalışmada e-wom'un “tüketici görüşleri”, "güvenilirlik-geçerlilik", "inanılırlık” ve "ilgilenim" faktörlerinin etkileri incelenmiştir.

\section{Bulgular ve Tartışma}

\subsection{Demografik Analiz}

Ankete katılan 222 kişiye ait demografik bulgular Tablo 1'de gösterilmiştir. Buna göre; katılımcıların \%61.71'i kadın, \%38.29'u erkektir. Analize göre \% 34.68'i 18-27 yaş arasında, \%40.99'u 28-37 yaş arasında, \%17.56'sı 38-47 yaş arasında ve \%6.75'i 48 yaş ve üstündedir.

Çalışmada eğitim düzeyi 6 seviyeye ayrılmıştır. Sonuçlar incelendiğinde çalışmanın \%39.63'ünü lisans mezunları, \%29.27'sini de lise mezunları oluşturmaktadır. Bu iki grup toplamda neredeyse anketörlerin \%70'ini oluşturmaktadır. Bunun dışında kalan kesimin ise $\% 2.7$ 'si ilkokul, $\% 1.35$ 'i ortaokul, \% 19.36's1 yüksekokul ve \%7.65'i ise lisansüstü mezunudur.

Ankete katılanların \%6.3'ü günde 1 saatten az, \%35.13’ü günde 1-2 saat aras1, \%33.33’ü günde 3-5 saat arası ve \%25.22'si günde 5 saatten fazla internet kullanmaktadır. 
Tablo1.Katılımcıların Demografik Özellikleri

\begin{tabular}{|c|c|c|}
\hline & Frekans & Yüzde $(\%)$ \\
\hline \multicolumn{3}{|l|}{ Cinsiyet } \\
\hline Kadın & 137 & 61.71 \\
\hline Erkek & 85 & 38.29 \\
\hline \multicolumn{3}{|l|}{ Yaş } \\
\hline $18-27$ & 77 & 34.68 \\
\hline $28-37$ & 91 & 40.99 \\
\hline $38-47$ & 39 & 17.56 \\
\hline 48 ve 48 yaş üzeri & 15 & 6.75 \\
\hline
\end{tabular}

\begin{tabular}{|l|c|c|}
\hline \multicolumn{1}{|c|}{ Eğitim Durumu } & Frekans & Yüzde (\%) \\
\hline İlkokul & 6 & 2.7 \\
\hline Ortaokul & 3 & 1.35 \\
\hline Lise & 65 & 29.27 \\
\hline Yüksekokul & 43 & 19.36 \\
\hline Lisans & 88 & 39.63 \\
\hline Lisansüstü & 17 & 7.65 \\
\hline Günlük İnternet Kullanma & & 6.3 \\
\hline Sıklığı & 14 & 35.13 \\
\hline 1 saatten az & 78 & 33.33 \\
\hline $1-2$ saat arası & 74 & 25.2 \\
\hline 3-5 saat arası & 56 & \\
\hline 5 saatten fazla & & \\
\hline
\end{tabular}

\subsection{Faktör Analizi}

Çalışmada e-wom'un tatil satın alma niyetine etkisini ölçmek için oluşturulan 20 sorulu ölçeğe faktör analizi uygulanmıştır. Bu analizde faktör yükü 0,5 'den düşük olan ifadeler formdan çıkarılmış ve tüm ifadelerin faktör yükleri 0,50 'nin üstünde olana kadar faktör analizi tekrarlanmıştır. Sonuç olarak bağımlı değişken ifadeleri hariç 15 ifade 4 faktör altında toplanmıştır. Faktör analizine ait Kaiser Meyer Olkin (KMO) değeri 0,845 olarak hesaplanmıştır yani, örneklemin faktör analizi için yeterli olduğu söylenilebilir. Ayrıca çalışmanın Cronbach's Alpha değeri 0.880 olarak bulunmuştur. Bu değer anketin güvenilir satılabilmesi için yeterlidir. Faktör analizi sonuçları Tablo 2'de verilmiştir. 
Ölçeğin açıklanan varyansı tüketici görüşleri faktörü için \%26,649, güvenilirlik-geçerlilik faktörü için \%15,612, ilgilenim faktörü için \%10,580 ve inanılırlık faktörü için \%12,131 olarak bulunmuştur. Açılanan toplam varyans \%64,971 dir.

Tablo 2. Faktör Analizi Sonucu

\begin{tabular}{|c|c|c|c|c|c|}
\hline Faktör & & $\boldsymbol{\mu}$ & $\mathbf{S}$ & $\begin{array}{l}\text { Faktör } \\
\text { Yükü }\end{array}$ & $\begin{array}{l}\text { Açıklanan } \\
\text { Varyans } \\
(\%)\end{array}$ \\
\hline \multirow[t]{5}{*}{$\begin{array}{l}\text { Tüketici } \\
\text { Görüsşleri } \\
(\mu=3,605)\end{array}$} & $\begin{array}{l}\text { Web sitesinde yayınlanan görüşlerin } \\
\text { tutarlılığı, tatil tercihi ve satın alma kararımı } \\
\text { etkiler }\end{array}$ & 3,61 & 0,999 & 0,626 & \multirow[t]{5}{*}{26,649} \\
\hline & $\begin{array}{l}\text { Web sitelerinde sunulan negatif görüşler, } \\
\text { tatil satın alma kararımda etkilidir }\end{array}$ & 3,61 & 0,843 & 0,841 & \\
\hline & $\begin{array}{l}\text { Web sitelerinde sunulan pozitif görüşler, } \\
\text { tatil satın alma kararımda etkilidir }\end{array}$ & 3,65 & 0,867 & 0,861 & \\
\hline & $\begin{array}{l}\text { Tatil paketleri için yapılan yüksek } \\
\text { derecelendirme tatil satın alma kararımı } \\
\text { etkiler }\end{array}$ & 3,51 & 0,950 & 0,604 & \\
\hline & $\begin{array}{l}\text { İnternette bir tatil rezervasyonu } \\
\text { yaptıracağım zaman web sitelerinde sunulan } \\
\text { görüşler, vereceğim satın alma kararında } \\
\text { yardımcı olur }\end{array}$ & 3,64 & 0,886 & 0,774 & \\
\hline \multirow{4}{*}{$\begin{array}{l}\text { Güvenilirlik- } \\
\text { Geçerlilik } \\
(\mu=3,68)\end{array}$} & $\begin{array}{l}\text { Yorumcuların takma adları veya gerçek } \\
\text { isimleri tatil satın alma kararımı etkiler }\end{array}$ & 3,09 & 1,098 & 0,463 & \multirow[t]{4}{*}{15,612} \\
\hline & $\begin{array}{l}\text { Görüşleri sunan web sitesinin güvenilirliği } \\
\text { tatil satın alma kararımı etkiler }\end{array}$ & 3,82 & 0,931 & 0,550 & \\
\hline & $\begin{array}{l}\text { Görüşleri sunan web sitesinin uluslararası } \\
\text { geçerliliği tatil satın alma kararımı etkiler }\end{array}$ & 3,74 & 0,957 & 0,583 & \\
\hline & $\begin{array}{l}\text { Tatil satın alma karar sürecimde deneyim } \\
\text { sahibi kişilerden görüş ve destek alırım }\end{array}$ & 3,91 & 0,961 & 0,728 & \\
\hline
\end{tabular}




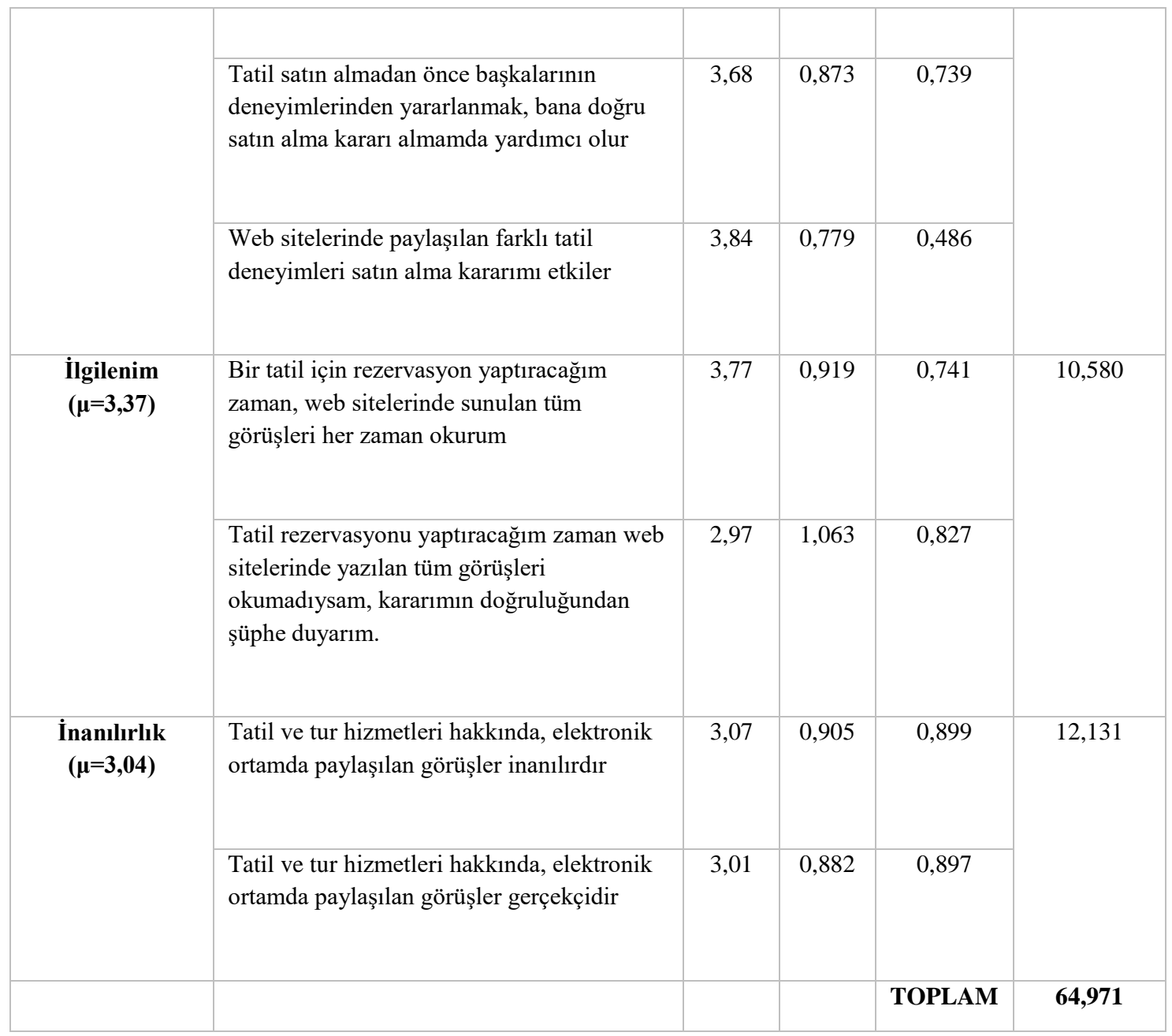

\subsection{Model ve Hipotez Testleri}

Tüketicilerin tatil satın alma niyeti ve tavsiye etmesinde e-wom faktörlerinin etkisini incelemek için yapılan bu çalışmanın modeli Şekil-1'deki gibidir:

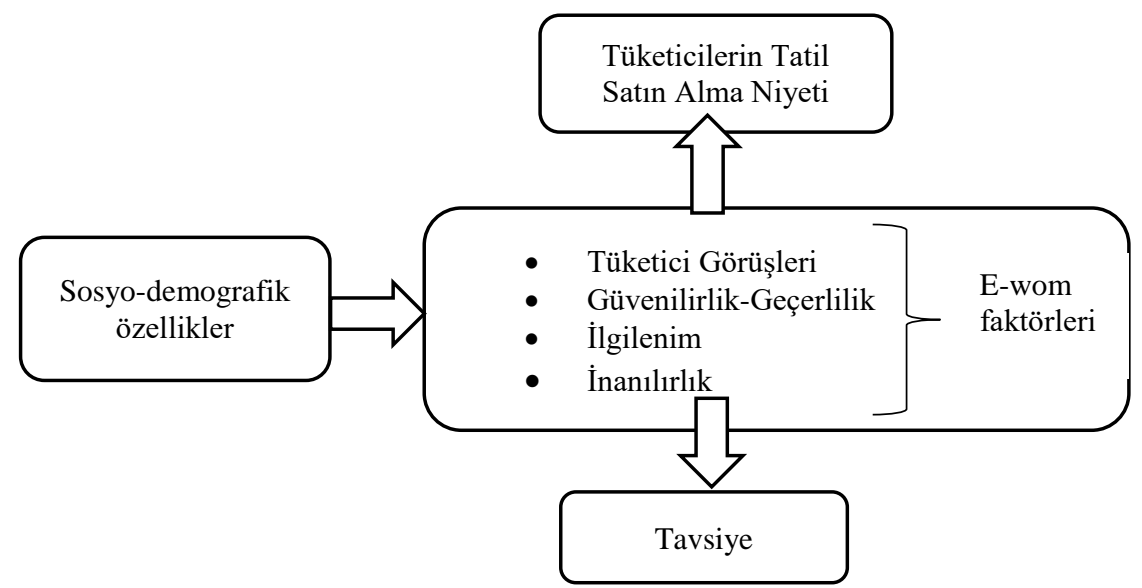


Araştırmanın amacı doğrultusunda her faktörün anketi uygulayanların demografik özelliklerine bağlı olarak anlamlı farklılık gösterip göstermediği, t-testi ve tek yönlü varyans analizi (ANOVA) ile analiz edilmiştir. E-wom faktörlerinin bağımlı değişkenler olan satın alma niyeti ve tavsiyeye olan etkileri ise çoklu regresyon analizi ile incelenmiştir.

Tüketicilerin sosyo-demografik özellikleri ile e-wom faktörlerinden tüketici görüşleri arasındaki ilişkinin incelenmesi için geliştirilen ana hipotez şöyledir:

$\mathrm{H}_{1}$ : Tüketicilerin sosyo-demografik özellikleri ile e-wom faktörlerine ilişkin tüketici görüşleri arasında anlamlı bir farklılık vardır.

\subsubsection{Cinsiyet Gruplarının Farklılığının Test Edilmesi}

E-wom'un 4 faktörüne ait ortalamalarda kadınlarla erkekler arasında anlamlı bir fark olup olmadığını tespit etmek için her bir faktöre bağımsız değişken $t$ testi uygulanmıştır. $\mathrm{Bu}$ incelemeler için geliştirilen hipotez:

$\mathrm{H}_{1 \mathrm{a}}$ : Cinsiyet ile e-wom faktörlerine ilişkin tüketici görüşleri arasında anlamlı bir farkl111k vardır.

Tablo 3.Cinsiyet için Bağımsız t-Testi

\begin{tabular}{|c|c|c|c|c|c|c|c|}
\hline & Kadın & Erkek & \multicolumn{2}{|c|}{ Levene Testi } & \multicolumn{3}{|c|}{ T- Testi } \\
& $(\mathbf{N = 1 3 7 )}$ & $\mathbf{( N = 8 5 )}$ & F & Sig. & $\begin{array}{c}\text { Varyans } \\
\text { Eşitliği }\end{array}$ & T değeri & Sig. \\
\cline { 3 - 7 } & 3,7007 & 3,4824 & 0,053 & 0,818 & var & $-2,244$ & $0,026^{*}$ \\
\hline $\begin{array}{c}\text { Tüketici } \\
\text { Görüşleri }\end{array}$ & 3,7066 & 3,6353 & 0,886 & 0,353 & var & $-0,784$ & 0,434 \\
\hline $\begin{array}{c}\text { Güvenilirlik- } \\
\text { Geçerlilik }\end{array}$ & 3,3686 & 3,3824 & 0,038 & 0,845 & var & 0,119 & 0,905 \\
\hline İlgilenim & 3,0584 & 3,0118 & 0,973 & 0,973 & var & $-0,408$ & 0,683 \\
\hline İnanılırlık & & & & & & & 0 \\
\hline
\end{tabular}

Tabloda görüldüğü üzere 0,05 anlamlılık düzeyinde sadece tüketici görüşleri için sig. değeri 0,026 olduğundan, tüketici görüşleri ile cinsiyet arasında anlamlı bir farklılık olduğu sonucu elde edilmiştir. Dolayısıyla geliştirilen hipotezden $\mathrm{H}_{1 \mathrm{a}}$ kabul edilmiş olur. Diğer faktörler ile cinsiyet arasında anlamlı bir farklılık tespit edilmemiştir. 


\subsubsection{Yaş Gruplarının Farklılığının Test Edilmesi}

Demografik unsurlardan biri olan yaş gruplarının arasında faktörler açısından anlamlı farklılık bulunup bulunmadığını test etmek için tek yönlü varyans analizi (ANOVA) yapılmıştır. Bunun için geliştirilen hipotez:

$\mathrm{H}_{1 \mathrm{~b}}$ : Yaş ile e-wom faktörlerine ilişkin tüketici görüşleri arasında anlamlı bir farklılık vardır.

Tablo 4: Yaş Grupları İçin ANOVA Analizi

\begin{tabular}{|c|c|c|}
\hline Faktör & F & Sig. \\
\hline Tüketici Görüşleri & 4,150 & $0,007^{*}$ \\
\hline Güvenilirlik-Geçerlilik & 2,182 & 0,91 \\
\hline İlgilenim & 0,268 & 0,848 \\
\hline İnanılırlık & 0,246 & 0,864 \\
\hline
\end{tabular}

ANOVA analizinin sonucuna göre sig. değeri 0,005 'den küçük olan sadece tüketici görüşleri faktörü olduğu için kurulan hipotez kabul edilmiştir. Diğer faktörler açısından anlamlı bir farklılık tespit edilmemiştir. Ayrıca yapılan Post Hoc Testi 1827 yaş grubu ile 38 ve üstü yaş grupları arasında anlamlı farklılık olduğunu göstermektedir.

\subsubsection{Eğitim Düzeyleri Farklılığının Test Edilmesi}

Demografik özelliklerden eğitim düzeylerinin arasında faktörler açısından anlamlı farklılık gözlenip gözlenmediğini incelemek için tek yönlü varyans analizi (ANOVA) yapılmıştır. Bunun için geliştirilen hipotezler:

$\mathrm{H}_{1 c}$ : Eğitim düzeyi ile e-wom faktörlerine ilişkin tüketici görüşleri arasında anlamlı bir farklılık vardır.

$\mathrm{H}_{1 \mathrm{~d}}$ : Ĕ̆itim düzeyi ile e-wom faktörlerine ilişkin güvenilirlik-geçerlilik arasında anlamlı bir farkl1lı vardır.

Tablo 5: Eğitim Düzeyleri İçin ANOVA Analizi

\begin{tabular}{|c|c|c|}
\hline Faktör & F & Sig. \\
\hline Tüketici Görüşleri & 2,607 & $0,026^{*}$ \\
\hline Güvenilirlik-Geçerlilik & 3,381 & $0,006^{*}$ \\
\hline İlgilenim & 0,390 & 0,855 \\
\hline İnanılırlık & 1,143 & 0,339 \\
\hline
\end{tabular}


Yapılan ANOVA analizinin sonucuna göre, 0,05 anlamlılık düzeyinde sadece tüketici görüşleri ve güvenilirlik-geçerlilik faktörleri bulunmaktadır. Dolayısıyla eğitim düzeyleri ile bu faktörler arasında istatistiksel açıdan anlamlı farklılık tespit edilmiştir. Hipotezler kabul edilmiştir. Yapılan Post Hoc Testinin sonucuna göre de anlamlı farkl1lı lise ve lisans düzeylerinde saptanmıştır.

\subsubsection{Günlük İnternet Kullanım Süresi Farklılıklarının Test Edilmesi}

Bir kullanıcı özeliği olan günlük internet kullanma sürelerinin faktörler açısından arasında anlamlı farklılık bulunup bulunmadığını tespit etmek için tek yönlü varyans analizi (ANOVA) yapılmıştır. Bunun için geliştirilen hipotezler:

$\mathrm{H}_{1 \mathrm{e}}$ : Tüketicilerin günlük internet kullanma süresi ile e-wom faktörlerine ilişkin tüketici görüşleri arasında anlamlı bir farklılık vardır.

Tablo 6: Günlük İnternet Kullanma Süresi İçin ANOVA Analizi

\begin{tabular}{|c|c|c|}
\hline Faktör & F & Sig. \\
\hline Tüketici Görüşleri & 4,893 & $0,003^{*}$ \\
\hline Güvenilirlik-Geçerlilik & 1,053 & 0,370 \\
\hline İlgilenim & 0,198 & 0,898 \\
\hline İnanılırlık & 1,001 & 0,393 \\
\hline
\end{tabular}

Analiz sonucuna göre anlamlılık düzeyi 0,005 in altında olan tek faktör tüketici görüşleridir. Bu yüzden hipotez doğru kabul edilir. Post Hoc testinin sonucuna göre de günde en fazla 2 saat internet kullanan tüketiciler ile 5 saatten fazla internet kullanan tüketiciler arasında anlamlı farklılık tespit edilmiştir.

\subsubsection{Satın Alma Niyeti Çoklu Regresyon Modeli}

Araştırmanın anketinde bulunan "Web sitelerindeki görüşlere dayalı olarak, bir tatil satın alacağım" ve "Web sitelerindeki görüşlere dayalı olarak, arkadaşlarıma tatil satın almalarını tavsiye edeceğim" ifadeleri faktör analizinden çıkarılmış ve tekrar kalan ifadeler için faktör analizi tekrarlanmıştır. Analiz sonunda elde edilen dört faktör bağımsız değişkenler olarak satın alma niyeti ve tavsiye etme durumu bağımlı değişkenler olarak çoklu regresyon analizine tabi tutulmuştur. Bu analiz için test edilmesi gereken hipotezler ise şöyledir:

$\mathrm{H}_{2}$ : E-wom faktörleri ile tüketicilerin tatil satın alma niyeti arasında bir ilişki vardır. 
$\mathrm{H}_{2 \mathrm{a}}$ : E-wom faktörlerine ilişkin tüketici görüşleri ile tüketicilerin tatil satın alma niyeti arasında bir ilişki vardır.

$\mathrm{H}_{2 \mathrm{~b}}$ : E-wom faktörlerine ilişkin güvenilirlik-geçerlilik ile tüketicilerin tatil satın alma niyeti arasında bir ilişki vardır.

Tablo 7'den de anlaşılabileceği gibi satın alma niyetinin e-wom faktörleriyle olan ilişkisinin 0,508 olduğu ve e-wom faktörlerinin satın alma niyeti üzerindeki değişimin \%24,5'ini açıklayabildiği görülmektedir.

Tablo.7: Satın Alma Niyeti Regresyon Modeli Özeti

\begin{tabular}{|c|c|c|c|c|}
\hline Model & R & R Kare & Düzeltilmiş R Kare & Standart Hata Oranı \\
\hline 1 & 0,508 & 0,258 & 0,245 & 0,863 \\
\hline
\end{tabular}

Tablo.8: Satın Alma Niyeti Regresyon Modeli ANOVA Tablosu

\begin{tabular}{|c|c|c|c|c|c|c|}
\hline Model & & $\begin{array}{c}\text { Karelerin } \\
\text { Toplamı }\end{array}$ & $\begin{array}{c}\text { Serbestlik } \\
\text { derecesi }\end{array}$ & $\begin{array}{c}\text { Ortalama } \\
\text { Kare }\end{array}$ & F & Anlamlılık \\
\hline \multirow{2}{*}{1} & Regresyon & 56,314 & 4 & 14,079 & 18,897 & 0,000 \\
\cline { 2 - 7 } & Kalıntı & 161,668 & 217 & 0,745 & & \\
\cline { 2 - 7 } & Toplam & 217,982 & 221 & & & \\
\hline
\end{tabular}

Modelin anlamlılık seviyesi 0,000 olduğu için bağımlı değişkenin bağımsız değişkenlerle tahmin edilmesinin istatistiksel açıdan mümkün olduğu anlaşılmaktadır.

Tablo.9: Satın Alma Niyeti Regresyon Analizi Sonucu

\begin{tabular}{|c|c|c|c|c|c|c|}
\hline & & $\begin{array}{l}\text { Standardize } \\
\text { Olmayan } \\
\text { Katsayılar }\end{array}$ & $\begin{array}{l}\text { Standardize } \\
\text { Olmuş } \\
\text { Katsayılar }\end{array}$ & T değeri & Anlamlılık & VIF Değeri \\
\hline Model & B & Beta & & & \\
\hline 1 & (Sabit) & $-0,143$ & & $-0,368$ & 0,713 & \\
\hline & Tüketici Görüşleri & 0,434 & 0,311 & 3,927 & $0,000^{*}$ & 1,834 \\
\hline & $\begin{array}{l}\text { Güvenilirlik- } \\
\text { Geçerlilik }\end{array}$ & 0,253 & 0,167 & 2,211 & $0,028^{*}$ & 1,675 \\
\hline & İlgilenim & 0,123 & 0,103 & 1,621 & 0,107 & 1,185 \\
\hline & İnanılırlık & 0,078 & 0,065 & 1,045 & 0,297 & 1,126 \\
\hline
\end{tabular}


Yukarıdaki tabloda görüldüğü üzere, regresyon analizi sonucunda tatil satın alma niyetine anlamlı olarak etki eden faktörler, standardize olmuş Beta katsayıları dikkate alınarak şöyle ifade edilebilir:

Satın Alma Niyeti

$$
\begin{aligned}
& =-0,143+0,311 \text { (tüketici görüşleri) }+0,167 \text { (güvenilirlik } \\
& - \text { geçerlilik) }
\end{aligned}
$$

\subsubsection{Tavsiye Etme Çoklu Regresyon Modeli}

Çalışmanın bu bölümünde test edilmesi gereken hipotez:

$\mathrm{H}_{3}$ : E-wom faktörlerine ilişkin tüketici görüşleri ile tüketicilerin tatil tavsiye etmesi arasında bir ilişki vardır.

Tavsiye etme durumu bağımlı değişkeni ve e-wom'un dört faktörü bağımsız değişkenleri oluşturmak üzere kurulmuş olan regresyon modelinde tablo 10'dan anlaşllabileceği üzere bağımlı değişkenin bağımsız değişkenlerle ilişkisinin 0,440 olduğu ve bağımsız değişkenlerin bağımlı değişken üzerindeki değişimin sadece \%17,9'unu açıklayabildiği görülmektedir.

Tablo.10: Tavsiye Regresyon Modeli Özeti

\begin{tabular}{|c|c|c|c|c|}
\hline Model & R & R Kare & Düzeltilmiş R Kare & Standart Hata Oranı \\
\hline $\mathbf{1}$ & 0,440 & 0,193 & 0,179 & 0,981 \\
\hline
\end{tabular}

Modelin anlamlılık seviyesi 0,000 olduğu için bağımlı değişkenin bağımsız değişkenlerle tahmin edilmesinin istatistiksel açıdan mümkün olduğu anlaşılmaktadır.

Tablo.11: Tavsiye Regresyon Modeli ANOVA Tablosu

\begin{tabular}{|c|c|c|c|c|c|c|}
\hline Model & & $\begin{array}{c}\text { Karelerin } \\
\text { Toplamı }\end{array}$ & $\begin{array}{c}\text { Serbestlik } \\
\text { derecesi }\end{array}$ & $\begin{array}{c}\text { Ortalama } \\
\text { Kare }\end{array}$ & F & Anlamlılık \\
\hline \multirow{2}{*}{1} & Regresyon & 50,068 & 4 & 12,517 & 13,007 & 0,000 \\
\cline { 2 - 7 } & Kalıntı & 208,820 & 217 & 0,962 & & \\
\cline { 2 - 7 } & Toplam & 258,887 & 221 & & & \\
\hline
\end{tabular}


Analiz sonucunda tavsiye etme durumuna istatistiksel açıdan anlamlı olarak etki eden tek faktör tüketici görüşleridir. Buna göre oluşan regresyon denklemini aşağıdaki şekilde ifade edebiliriz:

$$
\text { Tavsiye etme durumu }=0,221+0,335 \text { (tüketici görüşleri) }
$$

Tablo.12: Tavsiye Regresyon Analizi Sonucu

\begin{tabular}{|c|l|c|c|c|c|}
\hline & & $\begin{array}{l}\text { Standardize } \\
\text { Olmayan } \\
\text { Katsayılar }\end{array}$ & $\begin{array}{l}\text { Standardize } \\
\text { Olmuş } \\
\text { Katsayılar }\end{array}$ & T değeri & Anlamlılık \\
\hline Model & & $\mathbf{B}$ & Beta & & \\
\hline 1 & (Sabit) & 0,221 & & 0,500 & 0,618 \\
\hline & Tüketici Görüşleri & 0,509 & 0,335 & 4,054 & 0,000 \\
\hline & $\begin{array}{l}\text { Güvenilirlik- } \\
\text { Geçerlilik }\end{array}$ & 0,176 & 0,107 & 1,354 & 0,177 \\
\hline & $\begin{array}{l}\text { İlgilenim } \\
\text { İnanılırlık }\end{array}$ & 0,078 & 0,060 & 0,923 & 0,357 \\
\hline
\end{tabular}

\section{Bulgular ve Sonuçlar}

İnternetin hayatımızın her alanını kapladığı şu günlerde bir ürün ya da hizmet satın almadan önce çevrimiçi görüşlere başvuran tüketici sayısı hızla artmaktadır. Neredeyse satın alınan tüm ürünler için daha önce bu ürünleri kullananların deneyimlerinden yararlanıyoruz ya da bu ürünlerle ilgili satın alma bilgilerine ulaşıyoruz. Bunun yanında çoğu zaman kendimizde deneyimlediğimiz ürün ya da hizmet hakkında olumlu ya da olumsuz çevrimiçi platformlarda görüş bildiriyoruz. Böylelikle milyonlarca insanın görüşünü paylaştığı ortamlar oluşmaktadır. Bu çalışmada da tüketicilerin okudukları görüşlerin tatil satın alma niyetine ve tavsiye etmesine etkisi tespit edilmeye çalışılmıştır.

Araştırmada e-wom'un tüketicilerin tatil satın alma niyetine etki eden faktörlerinin etki dereceleri çoklu regresyon analizi ile tespit edilmeye çalışılmıştır. Yapılan analiz sonucunda istatistiksel olarak anlamlı şekilde tüketici görüşlerinin 0,311 katsayısı ile satın alma niyetini etkilediği sonucuna varılmıştır. Almana ve Mirza (2013)'nın çalışmasında bu faktörün ortalaması yaklaşık $3.66 \mathrm{iken}$ bu çalışmada ki ortalama yaklaşık 3.61 bulunmuştur. Tüketici görüşleri faktörünün en yüksek ortalamaya sahip yargısı pozitif görüşlerin satın alma kararını etkilediğidir. Wei vd. (2014) de yaptığ 1 çalışmada pozitif çevrimiçi görüşlerin (Beta=0,293) rezervasyon niyetini anlamlı olarak etkilediğini bulmuştur. Ayrıca Chen vd. (2015)'de pozitif e-wom'un satın alma kararında önemli bir doğrulayıcı araç olarak göstermektedir. Çalışmalar bu konuda paralellik göstermektedir, ancak Park ve Lee (2009) çalışmasında ewom etkisinin negatif e-wom için pozitif e-wom için olduğundan daha fazla olduğu sonucunu elde etmiştir. Almana ve Mirza (2013) ürünler için yapılan yüksek 
derecelendirmenin ölçek ortalamasını 3,86 olarak bulmuştur. Çalışmamızda tüketici görüşleri faktöründe yer alan bu ifadenin ölçek ortalaması 3,51 olarak elde edilmiştir.

Güvenilirlik-geçerlilik faktörünün satın alma niyetini $(0,167)$ kadar etkilediği elde edilmiştir. $\mathrm{Bu}$ faktör altında görüşlerin okunduğu web sitesinin uluslararası geçerliliği ve güvenilirliği de tatil satın alma niyetini etkilediği görülmüştür. Almana ve Mirza (2013) yaptığı çalışmada web sitesinin güvenilirliğinin $(3,81)$ ve uluslararası geçerliliğinin $(3,62)$ ölçek ortalamasını "katıllyorum" derecesine yakın bulmuştur. Bu çalışmada da web sitesinin güvenilirliğinin ortalamasının 3,82 ve uluslararası geçerliliğinin ortalamasının 3,74 olduğu görülmektedir. $\mathrm{Bu}$ sonuçlara bakarak tüketicilerin görüşleri okudukları web sitelerine önem verdikleri sonucuna varılabilir. Ayrıca bu faktördeki en ağırlıklı etkinin müşteri deneyimlerinden faydalanmak olduğu sonucuna ulaşılır. Thurau ve Walsh (2003) ve Thurau vd. (2004) çalışmalarında da müşteri deneyimlerinin satın alma kararına etkisi açıkça görülmektedir.

İlgilenim ve inanılırlık faktörlerinin istatistiksel açıdan anlamlı olarak satın alma niyetini etkilemediği sonucuna varılmıştır, fakat Wei vd (2014)'nin çalışmasında ilgilenim boyutunun satın alma niyetini etkilediği sonucu istatistiksel açıdan anlamlı olarak bulunmasına rağmen inanılırlık faktörünün satın alma niyetine etkisi bulunmamıştır. Fakat Park vd. (2007) çalışmasında ilgilenim boyutunun görüşlerin sayısı ve kalitesiyle ilişkisi kurulmuş ve satın alma niyetinde stratejik bir faktör olduğu belirtilmiştir.

Tüketici görüşlerinin, özellikle pozitif tüketici görüşlerinin, satın alma kararını olumlu yönde etkilediğini ve satın alımları arttırdığı göz önünde bulundurulursa, turizm sektöründeki firmaların internette, sundukları hizmetlerle ilgili yazılmış olan olumlu ve olumsuz görüşleri çok dikkate almaları gerekmektedir. Hizmet sundukları kişilere farklı deneyimler yaşatmaya çalışarak müşteri memnuniyetini artırmaya çalışmalıdırlar. Görüşlerin paylaşılabildiği rezervasyon sitelerinin de otel işletmecileri tarafından yakından takip edilerek eksiklerini hızlı gidermeleri tavsiye edilebilir. Böylelikle güzel tatil deneyimlerine sahip olan insanlar bunu yakınlarıyla da paylaşacak ve onları da oraya gitmeleri için yönlendirmiş olacaklardır.

$\mathrm{Bu}$ çalışmanın anketi sosyal ağlar aracılığıyla 280 kişiye ulaştırılmıştır ancak 222 verimli anket sonucu elde edilmiştir. Bu yüzden sonuçlar genellemez. Gelecekteki çalışmalar da örneklem sayısı artırılarak analizler yeniden yapılabilir ve e-wom'un farklı faktör boyutları da modele eklenilerek model geliştirilebilir. 


\section{KAYNAKÇA}

AL MANA, A. M., \& MIRZA, A. A. (2013). The impact of electronic word of mouth on consumers' purchasing decisions. International Journal of Computer Applications, 82 (9).

ASLAM, S., JADOON, E., ZAMAN, K., \& GONDAL, S. (2011). Effect of word of mouth on consumer buying behavior. Mediterranean Journal of Social Sciences, 2 (3), 497507.

CHANG, H. H., \& WU, L. H. (2014). An examination of negative e-WOM adoption: Brand commitment as a moderator. Decision Support Systems, 59, 206-218.

CHEN, C. H., NGUYEN, B., KLAUS, P. P., \& WU, M. S. (2015). Exploring electronic word-of-mouth (eWOM) in the consumer purchase decision-making process: the case of online holidays-evidence from United Kingdom (UK) consumers. Journal of Travel \& Tourism Marketing, 32 (8), 953-970.

CHEUNG, C. M., LEE, M. K., \& RABJOHN, N. (2008). The impact of electronic word-ofmouth: The adoption of online opinions in online customer communities. Internet research, 18 (3), 229-247.

CHEUNG, M. Y., LUO, C., SIA, C. L., \& CHEN, H. (2009). Credibility of electronic wordof-mouth: Informational and normative determinants of on-line consumer recommendations. International Journal of Electronic Commerce, 13 (4), 9-38.

CHEVALIER, J. A., \& MAYZLIN, D. (2006). The effect of word of mouth on sales: Online book reviews. Journal of marketing research, 43 (3), 345-354.

GOLDSMITH, R. E., \& HOROWITZ, D. (2006). Measuring motivations for online opinion seeking. Journal of interactive advertising, 6 (2), 2-14.

FAN, Y. W., MIAO, Y. F., FANG, Y. H., \& LIN, R. Y. (2013). Establishing the adoption of electronic word-of-mouth through consumers' perceived credibility. International Business Research, 6 (3), 58.

FILIERI, R., \& MCLEAY, F. (2014). E-WOM and accommodation: An analysis of the factors that influence travelers' adoption of information from online reviews. Journal of Travel Research, 53 (1), 44-57.

HENNIG-THURAU, T., GWINNER, K. P., WALSH, G., \& GREMLER, D. D. (2004). Electronic word-of-mouth via consumer-opinion platforms: what motivates consumers to articulate themselves on the internet?. Journal of interactive marketing, 18 (1), 38-52.

HENNIG-THURAU, T., WALSH, G., \& WALSH, G. (2003). Electronic word-of-mouth: Motives for and consequences of reading customer articulations on the internet. International journal of electronic commerce, 8 (2), 51-74. 
KALPAKLIOĞLU, N. Ü. (2015). Bir Pazarlama İletişimi Unsuru Olarak E-Wom'un Turizm Ürünleri Tercihine Etkisi. Maltepe Üniversitesi Illetişim Fakültesi Dergisi, 2 (1), 6690.

KHAMMASH, M. (2008, January). Electronic word-of-mouth: Antecedents of reading customer reviews in on-line opinion platforms: A quantitative study from the UK market. In Proc. IADIS International Conference WWW/Internet (Vol. 2008).

LITVIN, S. W., GOLDSMITH, R. E., \& PAN, B. (2008). Electronic word-of-mouth in hospitality and tourism management. Tourism management, 29 (3), 458-468.

LUO, C., LUO, X. R., SCHATZBERG, L., \& SIA, C. L. (2013). Impact of informational factors on online recommendation credibility: The moderating role of source credibility. Decision Support Systems, 56, 92-102.

PARK, C., \& LEE, T. M. (2009). Information direction, website reputation and eWOM effect: A moderating role of product type. Journal of Business research, 62 (1), 6167.

PARK, D. H., LEE, J., \& HAN, I. (2007). The effect of on-line consumer reviews on consumer purchasing intention: The moderating role of involvement. International journal of electronic commerce, 11 (4), 125-148.

POON, Y. L., LIM, C. Y., YONG, D. M. K., HIRIBAE, C. M., \& TAN, A. Y. W. (2014). eWoM Influence on Booking Intention: A study of hotels in KL (Doctoral dissertation, UTAR).

SPARKS, B. A., \& BROWNING, V. (2011). The impact of online reviews on hotel booking intentions and perception of trust. Tourism management, 32 (6), 1310-1323.

SEN, S., \& LERMAN, D. (2007). Why are you telling me this? An examination into negative consumer reviews on the web. Journal of interactive marketing, 21 (4), 76-94.

VIGLIA, G., MINAZZI, R., BUHALIS, D., (2016). The influence of e-word-of-mouth on hotel occupancy rate. International Journal of Contemporary Hospitality Management, 28 (9), 2035-2051.

WESTBROOK, R. A. (1987). Product/consumption-based affective responses and postpurchase processes. Journal of marketing research, 258-270. 